\title{
Joseph of Egypt: from a conflict maker to a conflict manager in the family
}

The role of Joseph from the Old Testament is interesting and important for several reasons. On the one hand, his behaviour caused conflicts within the family, while on the other, it was his behaviour and handling that led to the reconciliation of the family.

Joseph was the eleventh son of Jacob, but as the first son from Rachel, Jacob loved him more than the others. He was the firstborn of the wife that he "loved more." He was, therefore, the firstborn of pure love, and he enjoyed privileges with his father, despite his youth, and in a way enjoyed the privilege of the

* Rev. Stanko Gerjolj holds a PhD degree in theology from the University of Innsbruck (1986) and a PhD degree in pedagogy/psychology from the same university (1995). He is a professor of religious education and family counseling at the Faculty of Theology of the University of Ljubljana, as well as a member of the European Society of Catholic Theology, the Team of European Catechists, the Slovenian Psychologists Association, the Association for University Didactics, and the Slovenian Association of the Catholic Pedagogues. Currently, he is the chairman of the Association for Christian Gestalt Pedagogy in Europe, as well as the author of 5 scientific books ( 3 in Slovenian, 1 in German, and 1 in Croatian) and many scientific papers in different languages. He has also given guest lectures at different universities: Graz and Innsbruck (Austria), Zagreb, Split, and Pula (Croatia), Tuzla (Bosna and Herzegovina), Boston College and Niagara University (USA), and Shkodër (Albania).

1 Gen 29:30. 
firstborn. His status as the "firstborn" was probably further confirmed when his father realized that Reuben, his biological firstborn, "lay" with his "wife" Bilhah. ${ }^{2}$ It is possible that Jacob learned about this incident through Joseph, which must have weakened Joseph's relationship with his brothers, which had been probably tense since his birth anyway. But such information would have elevated his father's opinion of Joseph. Understandably, Jacob sees him as his "firstborn" after this event, and gives him the privileges that accompany that status. Jacob wants Joseph, as his "firstborn" and beloved, to experience as many things as he missed being a child himself. Privileges are then not limited to spoiling, but guarantee higher quality of life for him, and give him institutional power, especially in his communication with his brothers. ${ }^{3}$

\section{Joseph's youthful dream}

Jacob has an experience of crossing and "transcending" traditional bonds of family roles, which is why he probably finds it easy to transfer the firstborn status from Reuben to Joseph. Knowing his personal experience, he is probably motivated enough for such transition too.

As his mother's favorite, Jacob spent his childhood without a "firstborn" relationship with his father Isaac. Perhaps, as a form of compensation, Jacob is attached to his "firstborn through the status" and shows him more fatherly intimacy and warmth than to his other children. The tunic that Jacob makes for Joseph represents more than just material and other, secondary privileges. ${ }^{4}$ After all, this kind of tunic represented a higher class; ${ }^{5}$ in fact, it symbolizes royalty. ${ }^{6}$

2 Cf. Gen 35:22.

3 Cf. J. N. Cohen, Self, struggle \& change: family conflict stories in Genesis and their healing insights for our lives, Woodstock 1995, p. 153.

4 "When Joseph was seventeen years old, he was tending the flocks with his brothers; he was an assistant to the sons of his father's wives Bilhah and Zilpah, and Joseph brought their father bad reports about them. Israel loved Joseph best of all his sons, for he was the child of his old age; and he had made him a long ornamented tunic. When his brothers saw that their father loved him best of all his brothers, they hated him so much that they could not say a kind word to him" (Gen 37:2-4).

5 Cf. E. J. Hartley, New international biblical commentary: Genesis, Peabody 2000, p. 310.

6 Cf. I. M. Rupnik, "Brate iščem”, Koper 2000, p. 33. 
The tunic, or coat, symbolizes protection and safety, warmth and "womb-like" freedom, but in a shortened form, as a coat, it symbolizes vitality, masculinity, and strength. In his childhood, his father's affection provides Joseph with a sense of security, warmth, and freedom, but in adolescence in accordance with signs of growing - Joseph transforms it into signs of power and arrogant leadership, which feed off his privileged status. ${ }^{7}$ The story hints that his brothers' hostility to Joseph is not just caused by them, but can be traced to Joseph's actions as well. Among other things, he was a tattletale in his naïve childhood and teenage years, trying to gain affection from his father. Perhaps he even filled in some missing information, or made up some stories if he needed his father's affection. His father Jacob was a great teacher of such communication. He used to talk in this manner to his father Isaac to the detriment of his older brother Esau. Even without direct rivalry, Joseph soon discovered the benefits of being on his father's good side, and kept exploiting this affection.

Based on his role, Joseph's dream is actually simple and understandable, and actually comes as a consequence of his status. ${ }^{8}$ Young people, in the first steps of growing up, are convinced that they are the "directors, writers, producers, and lead actors" in their environment and, in this time of life, often dream about the future and start acting out life events. ${ }^{9}$

Throughout his life Joseph was privileged. Even as a child he knew how to provoke his brothers and stay on his father's good side, which must have

7 Some interpretations see Joseph's tunic as Leah and Rachel's wedding gown, which was, according to traditions of the time, passed on to the firstborn, and gave him the right to leadership positions, and to formal execution of the role of the firstborn (Cf. J. N. Cohen, Self, struggle \& change..., p. 153).

8 "Once Joseph had a dream, and when he told his brothers, they hated him even more. He said to them, 'Listen to this dream I had. There we were, binding sheaves in the field, when suddenly my sheaf rose to an upright position, and your sheaves formed a ring around my sheaf and bowed down to it.' His brothers said to him, "Are you really going to make yourself king over us? Will you rule over us?" So they hated him all the more because of his dreams and his reports" (Gen 37:5-8).

9 The basic message of the dream does not change even if Joseph already outgrew puberty, and according to some traditions, he has begun to approach early adulthood as a seventeen year old. In that case, the pressure to achieve privileged status is higher, and emotional tension between the brothers is stronger (Cf. T. Watt, Joseph's dreams, in: Jung and the interpretation of the Bible, ed. L. D. Miller, New York 1995, p. 56). Even though years cannot be counted as an exact measuring unit in the Old Testament, it is interesting that the Bible explicitly says that Joseph was still a young man (Cf. Gen 37:2). 
been difficult for his brothers as his older peers. ${ }^{10}$ By entering adolescent stage of growing, in accordance with his psychological tendencies, he elevates his conviction of self-importance and "almightiness." It adds exaggeration and slight arrogance to his communication with peers, which is also normal for the youth. Because he has such a strong and vibrant imagination that it overcomes a sense of reality and even his intellect, he finds help in his dreams. As a reflection of his life, he sees a "dream-like" future for himself, and is convinced that he will rule over his peers and that his proud attitude will change them into his admirers and servants. ${ }^{11}$

The dream is not only a sign of his superiority and mental sovereignty, but is primarily a sign of Joseph's vulnerability, anxiety, and fear that his brothers will prevent him from achieving his goals. This mental tension between the feelings of superiority and vulnerability probably leads to the articulation of his inner conflict through a dream. ${ }^{12}$ The dream solves Joseph's inner conflict only to the point that it encourages him to verbalize it. Doing so, increases the tension, but at the same time the dream forces all of the culprits to actively participate in solving the problem.

The brothers were probably just as angered by Joseph's dreams and exaggeration, as they were by the fact that he acted and communicated with them in a superior way. It is interesting and understandable that he does not share his dream with the father, only his brothers. The Bible does not mention the father in connection with the first dream. Joseph apparently feels strong enough and does not need his father's help to control his competition. Jacob either does not know about Joseph's dreams, or lives in denial and ignores it. He does not do anything, but lets his sons argue. Because of their negative experiences, the brothers do not react with aggression, but instead seem worried and concerned. They pile up their aggression and wait for an opportune moment to release it.

Youthful dreams have no boundaries and keep escalating until they hit a wall of reality. His brothers' reaction after the first dream was clearly not convincing enough and did not stop him from exaggerating his importance

10 Cf. J. N. Cohen, Self, struggle \& change..., p. 153.

11 In this case, interpretation of Joseph's dream would have ended once they discovered that Joseph is narcissistic (Cf. T. Watt, Joseph's dreams, in: Jung and the interpretation of the Bible..., p. 60), which is one of many possible diagnoses.

12 Cf. T. Watt, Joseph's dreams, in: Jung and the interpretation of the Bible..., p. 59. 
and power. So Joseph shares his second dream, which elevates his role even more, again with his brothers first, but they do not react to it. Thus, he tells it to his father, who is also involved in it, together with his late wife, Joseph's mother. ${ }^{13}$ The fact that Joseph resurrects his mother in his dream suggests vulnerability and fear, and not superiority, because he is looking for support from the deceased to achieve his goals. ${ }^{14}$ The image in his dream points to his narcissistic vulnerability as well, because, unlike the natural order, he, as a "star," is placed in the center of the universe. All of this suggests that there is something "wrong" with Joseph's mental state.

Jacob sensed what was happening inside of Joseph. He at least had an idea about the relationships between Joseph and his brothers. Despite the size of the family, such tension cannot be hidden. Jacob then waited for an opportunity to frame his dream properly and bring Joseph down to earth.

From the point of psychological learning, Jacob reacted craftily and decently to Joseph's dream. Categorical denouncing of exaggeration does not work, because young people rebel and try to find excuses and arguments for it. If parents blame young people, it triggers them to shut off and hide from the parents. Jacob does not blame or denounce Joseph, but connects the content of his dream to reality and questions it. Finding connections with reality and doubting the exaggeration is the most successful method of communication when it comes to forming dreams about the future and recognizing our limitations. Young people are neither rejected nor blamed, but, as serious talking partners, challenged to weigh and reflect on their claims.

Jacob understands the context of Joseph's dream and probably recognizes his own mistakes in upbringing, but cannot change the past. His son now dreams the way he taught him to. He cannot violently change and correct Joseph's view of himself, his surroundings, and his childish vision. ${ }^{15}$ Instead of

13 "Then he had another dream, and told it to his brothers. 'Look, I had another dream,' he said; 'this time, the sun and the moon and eleven stars were bowing down to me.' When he told it to his father and his brothers, his father reproved him and asked, 'What is the meaning of this dream of yours? Can it be that I and your mother and your brothers are to come and bow to the ground before you?' So his brothers were furious at him but his father kept the matter in mind" (Gen 37:9-11).

14 Cf. T. Watt, Joseph's dreams, in: Jung and the interpretation of the Bible..., p. 61.

15 Cf. J. N. Cohen, Voices from Genesis: guiding us through the stages of life, Woodstock 1998, p. 132. 
using violence, he thinks about it and prepares a plan that will better prepare Joseph for socialization in adult society and adulthood in general.

\section{Jacob loses his son Joseph}

Jacob and Joseph have a well-tuned relationship. Joseph was accustomed to reporting his brother's actions to his father, because he most likely did that on a regular basis, without his father's prompting. Nevertheless, he is somewhat surprised by his father's request. ${ }^{16}$

Jacob's question suggests that it would be good if Joseph minded his brothers' affairs a little more. It seems as if he was surprised that he stayed at home, and did not join them. He does not send him to his brothers to control them, but to spend some time with them, to bond with them, saying, "Come and I will send you to them." It is obvious that the father is trying to resolve some tension between the brothers, and still hopes to achieve harmony in the family.

After Joseph's second dream, Jacob feels provoked to test his own role in the family, because his son is threatening and changing it. Joseph respects his status and distinguishes him from his brothers, but in their role he equates them, because the sun had to bow down just like the moon and the stars. ${ }^{17}$ When his father senses that the son sees him equal to his children, he decides to make Joseph equal to his brothers.

Joseph's "I am ready" expresses his fundamental and principal agreement, but he missed, or did not understand the words' true meaning, because his father has to repeat, or soften the message. Additional information is, in this case, actually softening the message. When he re-words the message, Joseph is given only part of his normal mission and status, with which he always talked to his brothers.

His father's request that Joseph goes to his brothers and become one of them surprised and humiliated him to the point that he simply did not

16 "One day, when his brothers had gone to pasture their father's flocks at Shechem, Israel said to Joseph, 'Are your brothers not tending our flocks at Shechem? Come and I will send you to them.' 'I am ready,' Joseph answered. 'Go then', he replied; 'see if all is well with your brothers and the flocks, and bring back word"' (Gen 37:12-14).

17 Cf. Gen 37:9. 
understand it. His brothers had been avoiding him, and perhaps even feared him, because he always came to them with some mandate and institutional power, which gave him the right to control them, but this time he would have to join them without power or mandate. But this is not his style, and does not agree with his status.

When Jacob hears Joseph's bewildered assent and realizes that he cannot change his son as quickly as he had hoped, he is looking for middle ground. He adds a mandate and a mission to the visit, but it is much different than it has usually been. ${ }^{18}$ This time, his mandate is not to look for mistakes and spy on his brothers, but to check if his brothers and the flocks are all doing "well." Jacob re-words his message and gives it a positive connotation, and thus indicates to Joseph that negative gossip does not interest him. This detail suggests that the story of Joseph is not primarily about conflict and envy, even though we learn plenty about that in it too. Envy is the primary reason for the brothers' revenge, because they occasionally completely lose control over themselves. ${ }^{19}$

It is quite possible that Joseph knows his relationship with the brothers better than his father does, because the brothers never shared their anger with Jacob, and his "infuriating" behavior, which was tolerated and possibly encouraged by their father, and only reveal it in their father's absence. Joseph might even be afraid to distance himself from his father, because that means that he is losing his protector. In an effort to improve the relations between Joseph and his brothers, his father Jacob, despite this fact, is sending him away. ${ }^{20}$

Joseph's long journey, and especially his aimless wandering in the field, confirms the assumption that his brothers' were distancing themselves from their father, as well as his fear of meeting them. "Unluckily," "a man" finds him,

18 Cf. Gen 37:2.

19 Cf. H. J. Walton, The NIV application commentary: from biblical text... to contemporary life, Grand Rapids 2001, p. 701.

20 "So he sent him off from the valley of Hebron. When Joseph reached Shechem, a man came upon him as he was wandering about in the fields. 'What are you looking for?' the man asked him. 'I am looking for my brothers', he answered. 'Please tell me where they are tending the flocks.' The man told him, 'They have moved on from here; in fact, I heard them say, «Let us go on to Dothan.»' So Joseph went after his brothers and found them in Dothan" (Gen 37:14-17). 
and sends him to Dothan, where they have departed. ${ }^{21}$ Joseph now cannot return to his father, saying that he could not find his brothers in Shechem.

Joseph's meeting of "a man" reminds us of how Jacob met "a man" at the River Jabbok. ${ }^{22}$ Despite an apparent connection, the difference between the two events is significant. Joseph meets the man while he is wandering through a field, while his father meets a man by the river, which is a symbol of a challenge in life; a challenge to cross to the "other side", i.e. into freedom and integrate the "other side." In accordance with his undefined goal, Joseph's "man" is calm and pleasant, because he is not trying to beat or integrate him, there are no rivers nearby; Jacob's man was much more aggressive, because he was next to a river, facing a challenge and could not retreat from Jacob anymore.

Joseph - without wrestling the man - turned to Dothan and approached his brothers. Because - unlike his father - he did not cross the river and defeat the "man," i.e. he did not accept his other side and did not integrate a "brotherly" dimension of life, he did not change his actions, either. His brothers recognized him from afar and saw no change in him.

Perhaps they were expecting him, and it seems that they are not surprised by the visit. Their whole plan is prepared very quickly, too. Without unnecessary arguing, they quickly decide what they will do with him, how they will do it, and what they will say to their father. ${ }^{23}$

The only one that "complicates" things and is being a little bit of a "wet blanket" is the oldest brother, Reuben, ${ }^{24}$ who symbolically represents Joseph's brothers' conscience. ${ }^{25}$

In accordance with the tradition, Reuben understands the role of the firstborn and without special instruction, simply by following the "natural law"

21 Dothan was about 19 miles from Shechem (Cf. Sveto pismo Stare in Nove zaveze: Slovenski standardni prevod iz izvirnih jezikov, Ljubljana 1997, p. 89).

22 Cf. J. N. Cohen, Self, struggle \& change..., p. 158.

23 "They saw him from a distance, and before he reached them, they plotted to kill him. They said to one another: 'Here comes that dreamer! Come now, let us kill him and throw him into one of the cisterns here; we could say that a wild beast devoured him. We will see then what comes of his dreams'” (Gen 37:18-20).

24 "But when Reuben heard this, he tried to save him from their hands, saying: 'We must not take his life.' Then Reuben said, 'Do not shed blood! Throw him into this cistern in the wilderness; but do not lay a hand on him.' His purpose was to save him from their hands and restore him to his father" (Gen 37:21-22).

25 Cf. I. M. Rupnik, “Brate iščem”, p. 37. 
accepts responsibility for his brothers, and assuming the risk of becoming unpopular. He has the most justified reason to be angry with him, because Joseph stole his status of the firstborn. Besides, his work immensely contributed to Joseph's birth in the first place. ${ }^{26}$ As the brother who is most affected by Joseph's adolescent behavior, he completely overcomes the temptation of revenge. Being a responsible firstborn, he looks for ways to save Joseph, his competitor, and bring him back to his father unharmed.

Apart from his ethical touch, Reuben maybe sees Joseph's saving as an opportunity to repay his father for the sin that he committed with his "wife" Bilhah. Whether we understand this "lying" with her literally or not, his action indicates that he is competing with his father, reaching in his domain, and endangering him. Reuben admits his sin and looks for opportunities to repay it. Perhaps he even sees this as his opportunity to reclaim the role of the firstborn.

Reuben also knows and understands his brothers' anger. But he knows and perhaps even partially understands his father's love for Joseph, because as the firstborn, he initially received more attention from his father than the other children did. At the same time, he is aware that he cannot go head-tohead with the "power of the masses," which is represented by his brothers, and defeat them, so he is looking for strategic solutions. Thus, he accepts part of their plan, but tames it in a way that Joseph stands a realistic chance of being saved.

In spite of his father's indirect suggestion to approach his brothers as their brother, Joseph carried all the symbols of his privilege, wearing his "tunic, the long ornamented tunic." As an adolescent, he used to "boast" before his brothers and acted like he was more important and stronger than he really was. Because he avoided the "man" and - unlike his father Jacob - did not wrestle him, he was also unable to accept his other side. Meeting "a man" did not change him, which is why he was still wearing the robe, a symbol of superiority and power.

26 He is the one who found mandrakes, which were associated with fertility, and brought them to his mother Leah. Rachel was later able to get it from her, and thus, after long infertility, conceived Joseph. But more important than the herb's symbolic aid to sexuality and fertility, is the fact that Reuben, by finding the mandrakes, opened communication between Rachel and Leah, and thus changed their family life (cf. Gen 30:14-24). 
His brothers are further angered by his arrogance. Understandably, they first take his robe, the symbol of safety and power, which he - according to his brothers undeservedly - received from his father, and which has always protected him. But this time his father sent him out of his safety zone, to a "foreign" land, where Joseph cannot "cling" to anything. Alone, without his father, his robe loses the energy, and does not provide either safety, or power. Without hesitation, his brothers strip him of it, and bring him down to earth - underneath them - into a cistern, where, in their opinion, he, at least temporarily, belongs. ${ }^{27}$

Reuben is probably hoping he can save him and bring him back to his father. But things change and spoil Reuben's plan when merchants, heading to Egypt, are passing by. When Reuben's brother Judas notices that, he quickly comes up with a proposal to sell Joseph. ${ }^{28}$

Judah must have been a leader among the brothers. ${ }^{29}$ With his sin, Reuben might have lost his brothers' trust, and the void was filled by Judah. Therefore, the brothers "obey" Juda's suggestion, and sell Joseph, their father's beloved son, into Egypt. Reuben tries to change Joseph's difficult situation at the last moment, but he is too late and cannot change the course of the matter. ${ }^{30}$ Hurt and disappointed, he has to admit that these hateful family relationships have become too much for him to handle. He was able to fulfill part of his plan, because Joseph was not killed. But the other part, selling him and thus at least temporarily "killing" him, happened in line with the original plan.

Reuben, therefore, was not strong enough to control the tense and conflictive relationships, and provide security for the family in his father's absence. Hoping to repay his father for having unjustifiably reached in

27 "So when Joseph came up to his brothers, they stripped him of his tunic, the long ornamented tunic he had on; then they took him and threw him into the cistern. The cistern was empty; there was no water in it. Then they sat down to eat" (Gen 37:23-25).

28 "Judah said to his brothers: "What is to be gained by killing our brother and concealing his blood? Come, let us sell him to these Ishmaelites, instead of doing away with him ourselves. After all, he is our brother, our own flesh.' His brothers agreed. Midianite traders passed by, and they pulled Joseph up out of the cistern. They sold Joseph for twenty pieces of silver to the Ishmaelites, who took him to Egypt" (Gen 37:26-28).

29 Cf. J. N. Cohen, Self, struggle \& change..., p. 160; E. J. Hartley, New international biblical commentary..., p. 314.

30 "When Reuben went back to the cistern and saw that Joseph was not in it, he tore his garments, and returning to his brothers, he exclaimed: 'The boy is gone! What am I going to do?"” (Gen 37:29-30). 
his dominion, he tried very hard to come through for his "father" and demonstrate responsibility by keeping everyone safe, but he failed. As a sign of powerlessness and disappointment he "had to" tear his garments, his own "robe." His father reacts similarly when he hears about the loss of his son. ${ }^{31}$

The brothers present the news to their father according to their initial, tragic version, saying that Joseph simply is not alive anymore. They return the bloody and wounded, crippled, and "disabled" robe that he made for Joseph. ${ }^{32}$ With this cruelty, they clearly demonstrate to him what they think about the role that he, as a father, lovingly bestowed on Joseph. Robe or tunic - security and power - is now just a bloody mess. Jacob's robe now becomes obsolete too, because, as a father, he was unable to either keep his favorite son safe or give him strength to live.

Jacob then, after his wife, whom he loved immensely, now loses his son too, whom he loved just as much. Just as he mourned for his wife years ago, he now mourns for his lost son.

\section{Joseph in Egypt}

After he came to Egypt, Joseph had to build his life on a new foundation, without his "robe." He was so far removed from his parents that he had to live completely independently.

His marriage to an Egyptian woman and his two children's names in particular, prove that he consciously started a new life in Egypt. He named the first child "Manasseh, meaning, 'God has made me forget entirely my troubles and my father's house;' and the second he named Ephraim, meaning, 'God has made me fruitful in the land of my affliction."' 33 The emphasis suggests

31 Cf. Gen 37:34.

32 “They took Joseph's tunic, and after slaughtering a goat, dipped the tunic in its blood. Then they sent someone to bring the long ornamented tunic to their father, with the message: 'We found this. See whether it is your son's tunic or not.' He recognized it and exclaimed: 'My son's tunic! A wild beast has devoured him! Joseph has been torn to pieces!' Then Jacob tore his garments, put sackcloth on his loins, and mourned his son many days. Though his sons and daughters tried to console him, he refused all consolation, saying, 'No, I will go down mourning to my son in Sheol.' Thus did his father weep for him. The Midianites, meanwhile, sold Joseph in Egypt to Potiphar, an official of Pharaoh and his chief steward" (Gen 37:31-36).

33 Gen 41:51-52. 
a break from the past. Based on his other actions, we can be certain that he did not run from the past. He also did not simply suppress it in his subconscience, but was able to process it and forgive his brothers. As he learned to accept his other, vulnerable and humble face in unforeseen pain, he also matured in his ability to forgive.

\subsection{Joseph proves to be a blessed person}

Midianites sell Joseph to Potiphar, ${ }^{34}$ who held a high position in Egypt. ${ }^{35}$ The Bible shows Joseph as a blessed man, enjoying above-average success. Everything that he attempted to do was successful. He also positively influenced his surroundings and changed everything for the better. He soon became popular and respected in his new environment. ${ }^{36}$ Even though his brothers "stripped him" of his clothes, Joseph is not as "naked" as we could have expected based on his childhood and youth. He was given a good character and qualities at home, which he is able to express much easier and more convincingly in a foreign land, where he has no support from his father, or the pressure and threats from his brothers. From the humane characteristics and moral quality viewpoint, he is one of the most perfect characters in the Old Testament. ${ }^{37}$

Joseph's fast and successful socialization confirms that he was not privileged by his father during his childhood and adolescence in the sense of being spoiled. Joseph's privilege in the family was that he received more security and power. His father gave him a "special robe," which provided him with more opportunities for personal growth and talent development. His brothers did not reproach him with being "lazy and spoiled," but with the fact that he - with the father's help and blessing - assumed the right to rule, control, and subdue them in order to achieve his own goals. Jacob's "mishap" in upbringing was that he trusted Joseph more than his other children, gave him significantly more value and opportunities, and provided better prospects in life for him than for the other children. Thus, he prepared him

\footnotetext{
34 Cf. Gen 37:36.

35 Cf. Sveto pismo Stare in Nove zaveze..., Ljubljana 1997, p. 90.

36 Cf. Gen 39:2-5.

37 Cf. T. Watt, Joseph's dreams, in: Jung and the interpretation of the Bible..., p. 55.
} 
for a "blessed life" at the expense of other children, and therefore prevented him to have natural communication with his peers.

As the first child of Rachel, who was infertile for a long time, he was long awaited, and expected more eagerly than an average baby, by both his father and mother. The prenatal period clearly prepared him for his life, because he was born in a situation that was very positive for him - everybody was expecting him, loved him, and was happy to see him. To his parents, he was a "special" baby even before he was born, which encouraged a longing, prenatal "trinitarian" communication (father-mother-son), which in turn provided strong roots for his positive self-image after he was born. After his birth, Jacob and Rachel continued to provide parental warmth and security for Joseph, and regularly provided him with challenges, which encouraged a sense of success as a primary value, which resulted in Joseph's positive self-image. When his mother dies giving birth to Benjamin, Jacob attends to Joseph with all of his fatherly strength.

Joseph, therefore, spent his childhood and youth feeling like he was special in comparison to the other children, whom, as a Rachel's firstborn, he certainly was to his father. With such positive self-image, Joseph survived all of his risks and chicanes until now, without suffering real physical damage. He arrived to Egypt feeling that, with his talents and capabilities, and with God's help, he could successfully start a new chapter in life. Just as when he was born, everybody loves him again, everything is going according to his plans, and he quickly becomes a blessing for his surroundings, where he lives and works diligently. Undoubtedly he is working through difficult inner battles, but does not succumb to them, and is encouraged by his initial success.

\subsection{Joseph proves to be a strong and dignified person}

We learn that, despite some of Joseph's youthful actions, Jacob did not just raise a "dreamer," but a moral, ethical, upright, and honest person, who has great self-respect. ${ }^{38}$

Joseph had a chance in Egypt to "sell" himself and enjoy the privileges. ${ }^{39}$ But the path to Egypt has thoroughly changed him. If we can see hints of

38 Cf. T. Watt, Joseph's dreams, in: Jung and the interpretation of the Bible..., p. 64.

39 Cf. I. M. Rupnik, "Brate iščem", p. 51. 
unhealthy narcissism in Joseph's dreams before he left his home, the trials which began when he lost his tunic and fell into the well, and continued on his way to Egypt where he was forced to depend on foreigners for everything, have completely healed him from these feelings. In the process he did not lose his dignity, and kept a healthy relationship with himself. When Potiphar's wife tries to seduce him, we can see that the reason that he turned her down is not some narcissistic fear; it is a deep moral sense of honesty, respect, and self-respect. ${ }^{40} \mathrm{After}$ his conflict with the brothers, this is the second time that he lost his cloak, or tunic, but even this time he is not as "naked" and helpless as Potiphar's wife would have wanted him to be. When his brothers "stripped him," he had to accept his other side and thus integrated his vulnerability. His actions have long ceased to reflect the formerly haughty and arrogant young man, and now display humility and modesty. ${ }^{41}$ After he accepted and loved himself in all of his poverty and helplessness, he no longer feels the need to hide his true nature. Thus, even when she stole his clothes, Potiphar's wife could not make him act in ways that are unworthy of human beings. According to his ethical, moral, and religious values, he does not explain why he "escaped" from the wife with fear or arrogant haughtiness, but frames his argument on respect for the master as her husband, her as his wife, God as the source of honesty and holiness of marriage, and for himself as a person who did not want to be used for temporal pleasures or unnecessarily burden his future. Joseph, through his colorful - flawed and painful, as well as successful

40 "Now Joseph was well-built and handsome. After a time, his master's wife looked at him with longing and said, 'Lie with me.' But he refused and said to his master's wife, 'Look, as long as I am here, my master does not give a thought to anything in the house, but has entrusted to me all he owns. He has no more authority in this house than I do. He has withheld from me nothing but you, since you are his wife. How, then, could I do this great wrong and sin against God?' Although she spoke to him day after day, he would not agree to lie with her, or even be near her. One such day, when Joseph came into the house to do his work, and none of the household servants were then in the house, she laid hold of him by his cloak, saying, 'Lie with me!' But leaving the cloak in her hand, he escaped and ran outside.

When she saw that he had left his cloak in her hand as he escaped outside, she cried out to her household servants and told them, ' [...] He came in here to lie with me, but I cried out loudly. When he heard me scream, he left his cloak beside me and escaped and ran outside.' She kept the cloak with her until his master came home. Then she told him the same story..." (Gen 39:6-17).

41 Cf. J. N. Cohen, Self, struggle \& change..., p. 171. 
and joyful - tradition of forming permanent spousal relationships, as well as through Jacob's deep and intense upbringing, was formed into a strong personality, who, in much tougher circumstances than his ancestors, better implements the dignity of a human person than they did. No one can take this inner coat away from him.

Joseph stays firm in his dignity even after the master puts him in jail. ${ }^{42}$ The Bible does not even mention him ever defending himself and arguing with the master. Despite the trust he received so quickly, he is aware that he is "a slave" and accepts this role, in spite of an unjust accusation. He, therefore, overcame the temptation of his "dream role," and ascended to a level of accepting even unjust circumstances without argumentation. We can assume that his confidence is so healthy, and his self-image, "worn" on encouraging experience of primary religious relationships, so positive that he does not see this injustice as being tragic, because he feels that God is with him and that he will overcome this trial as well.

\subsection{From a "dreamer" to an interpreter of dreams}

Thrust into this new situation, Joseph feels God's presence even in prison, and as a "blessed child," sees every situation as an opportunity for change. The power of sensible and positive communication continues to bring him success. ${ }^{43}$ Thus he is again quickly given responsibility, which he carries out exemplary. He accompanies other prisoners, and helps them out. When he is caring for them, he is challenged for the first time to interpret two of the prisoners' dreams. In the process, he humbly steps back and stresses that God is the one who is interpreting the dreams ${ }^{44} \mathrm{He}$ sees himself as a "tool," which transposes God's message, so that people can understand it. ${ }^{45}$ In the mirror of the cupbearer and baker's dreams, Joseph is given an opportunity look at his own personality in a mirror, and in the image of the cupbearer's dream recognizes his own ability and positive traits, which give him an optimistic outlook for the future. In the baker's dream, he recognizes how destructive

42 Cf. Gen 39:19-20.

43 Cf. Gen 39:21-23.

44 Cf. F. Bogzaran, D. Deslauriers, Integral dreaming: a holistic approach to dreams, New York 2013, pp. 23-24.

45 Cf. Gen 40:4-8. 
narcissistic longings are, and how they naively offer themselves to birds of prey, and cannot survive long. ${ }^{46}$ Thus, the insight into the dream further encourages him to purify his soul and prepare for a relaxed, more humane and less narcissistic planning of the future. ${ }^{47}$

A full two years later, Pharaoh has the famous dream about fat cows, which are devoured by skinny cows, and about the fat ears of grain, swallowed by the thin ones ${ }^{48}$. Because Pharaoh cannot interpret his own dreams, and cannot find anybody to do it for him, a former prisoner tells him about Joseph. Pharaoh has him called out of prison and asks for an interpretation. But Joseph, in his deeply religious posture again stresses, "It is not I [...] but God who will respond for the well-being of Pharaoh." 49 Then he listens to Pharaoh and delivers God's message. ${ }^{50}$

The basic emphasis of the dreams is probably easy to interpret, but to bring the content to life is a more challenging. ${ }^{51}$

Joseph keeps stressing the role of faith. He received the necessary wisdom from the deeply religious generations that came before him. Spirituality and healthy religious devotion are similar to culture and art: ${ }^{52}$ the fruits can be seen, and are ripe, only after many generations have diligently cared for them. When it comes to culture, spirituality, and religion, the heritage of previous generations influences how a personality is formed..$^{53}$ Joseph is therefore assisted by multi-generational and his own personal nurturing of religious spirituality, to deeply experience, understand, explore, and express

46 Cf. Gen 40:9-23.

47 Cf. T. Watt, Joseph's dreams, in: Jung and the interpretation of the Bible..., p. 69.

48 Cf. Gen 41:1-7.

49 Gen 41:16.

50 “Joseph said to Pharaoh: 'Pharaoh's dreams have the same meaning. God has made known to Pharaoh what he is about to do. The seven healthy cows are seven years, and the seven healthy ears are seven years - the same in each dream. [...] Seven years of great abundance are now coming throughout the land of Egypt; but seven years of famine will rise up after them, when all the abundance will be forgotten in the land of Egypt. [...] That Pharaoh had the same dream twice means that the matter has been confirmed by God and that God will soon bring it about. 'Therefore, let Pharaoh seek out a discerning and wise man and put him in charge of the land of Egypt"' (Gen 41:25-33).

51 Cf. F. Bogzaran, D. Deslauriers, Integral dreaming..., p. 246.

52 Cf. D. F. Fincham, I say a little prayer for you, in: Contemporary issues in family studies, eds. A. Abela, J. Walker, Oxford 2014, p. 345.

53 Cf. J. G. Janzen, Exodus, Louisville 1997, p. 23. 
his life. ${ }^{54}$ To interpret the dream does not mean to foretell the future, but to achieve such deep insight into past and present life that the future does not need to be foretold, but it reveals itself. This revelation cannot be compared to a mathematically-logical deduction, or to a probability calculation, but it is a fruit of holistic understanding and experiencing of reality in all of its dimensions, even religious one. ${ }^{55}$ Only holistic learning gives us the ability to make permanent decisions, which are rooted in deep insight of life. Joseph experienced life as a permanent and intimate communication between God and man, which is why God clearly interprets the dream through him, because he has such a strong elementary connection with God that he experiences all of his thoughts as an act of God. ${ }^{56}$

Joseph was a real man "on the outside," convincing enough, and as a transponder of God's messages he was humble enough that Pharaoh listened to him with good intentions. He does not stop with dream interpretation, but with his own initiative gives real suggestions on what to do about it. Pharaoh is so overwhelmed by these suggestions that it seem logical to entrust him with fulfilling his plan.

\subsection{Joseph as an honest person, responsible and ambitious, yet also social and religious}

Jacob's upbringing was not perfect and led Joseph to a foreign land, but it was good enough to prepare him for independent, dignified, and responsible

54 Cf. H. Cloud, J. Townsend, How people grow: what the Bible reveals about personal growth, Grand Rapids 2001, p. 271.

55 Religiousness is a cultural dimension of life and is, in a broad interpretation of the word, comparable to culture from the psychology of learning and education's viewpoints. Just as good musicians grow from the roots of musicians that came before them, good and trustful believers are fed by the living relationship with God, which was articulated by generations before them. Of course, God's intercession is probable, because faith is a gift. But because gratia supponit naturam, a fresh and living tradition - especially a non-violent and non-intrusive, yet persistent and constant one - represents the best roots for a healthy religious education (cf. S. Cavalletti, The religious potential of the child 6 to 12 years old, Chicago 2002, p. 109).

56 Sometimes, in prayer, we think of a solution to a problem that we had long been searching for. We are correct in perceiving it as a gift from God. Through prayer, we were able to distance ourselves from being entrapped in our daily life, which enabled us to achieve a holistic overview of the entire situation we are facing. From this, slightly distanced point of view, we realize the solution is "genius," yet logical. 
life in extremely difficult circumstances. If his father's possessiveness "forced" him to a foreign land, Joseph, in "diaspora," proved to be a well brought-up, culturally, religiously, ethically, and morally formed personality.

Joseph must have remembered the times when his father would pray, as well as his build pillars and altars. Family prayer was probably also common in his childhood. All of these memories preserved his religious sensibility and posture, and invigorated his relationship with God. Religious dimension of life has always supported him in times of trials and dangers, and also in his positive experiences. Based on this deep and sensitive religious posture, he interpreted dreams, which means that his faith deepened his understanding of life, and prepared him for life's challenges, which transcend cognitive approach. ${ }^{57}$ This intuitive and religiously-holistic view of real life challenges elevates him to the economically and politically most important role in Egypt. ${ }^{58}$ The same posture encourages him that he is not broken even by unjust punishment, because his Egyptian career begins in jail. Perhaps because he was capable of noble actions even in a hidden and unjust prison, ${ }^{59}$ Pharaoh trusted him so quickly and completely.

In this foreign land, Joseph is known to be a reliable person, capable of forming permanent relationships. Diligence and fortitude in his personal life have paid off, and he now feels capable of starting a family; which is how Pharaoh perceives him as well. ${ }^{60}$ The family that he created was not as large as his primary family was. He modeled the family, to which his father was born, and which had two children. In a milder way this, at least occasionally, reminded him of the difficulties that Esau and Jacob faced when they tried to form a permanent relationship. A so-called large family, probably reminded him too much of his pain, and as a father, he must have been more comfortable in his grandfather's role, than his own father's role.

57 Cf. F. Bogzaran, D. Deslauriers, Integral dreaming..., p. 45.

58 "So Pharaoh said to Joseph: 'Since God has made all this known to you, there is no one as discerning and wise as you are. You shall be in charge of my household, and all my people will obey your command. Only in respect to the throne will I outrank you.' [...] 'Look, I put you in charge of the whole land of Egypt"' (Gen 41:39-41).

59 Cf. I. M. Rupnik, "Brate iščem”, p. 64.

60 "Pharaoh also bestowed the name of Zaphenath-paneah on Joseph, and he gave him in marriage Asenath, the daughter of Potiphera, priest of Heliopolis. And Joseph went out over the land of Egypt" (Gen 41:45). 
During the time of rich years, Joseph was successful in creating a family, but also as the "Ruler of the Land." 61 As a successful "prime minister" he fulfills his adolescent dream, but now as an experienced, grown, and wellrounded man. Success and abundance did not overcome him, because he anticipated the crisis of "dry" years, which is what later greatly benefitted him. But it is not enough to see Joseph's actions as merely political pragmatism. Even altruism and social sense cannot fully explain them, because Joseph openly announces that God is giving him answers, which means that he "lives, works, and loves" in faith. Faith, which he had practiced before and which he strengthened in the diaspora, cannot be reduced to ethical, and even less so pragmatic actions. ${ }^{62}$ Faith overwhelms men, fills them up, and encourages them to form personal competence and virtues which transcend explanations. immanent Thus, his actions make more sense if we connect them to faith and consider his personal qualities, most noticeable of which is humility. ${ }^{63}$ All the humiliation did not break him, but strengthened his virtues. These points to Joseph's ability to forgive.

\section{Joseph educates about forgiveness and forgives}

When the seven rich years had passed, according to Joseph's foretelling, dry years started. But famine did not just strike Egypt, it struck their surrounding areas as well, including Canaan, where Joseph's brothers lived.

Joseph had collected enough food that he was now able to also help people who were not from Egypt. ${ }^{64}$ And so, instructed by Jacob, Joseph's brothers come seeking help as well. All of them came, except for their youngest, Benjamin. Jacob senses complications and therefore keeps Benjamin, after Joseph his second most beloved son, with him. ${ }^{65}$ Even though there was no tension between Benjamin and his brothers until then, this is not excluded, because he, as a son of Rachel, is "different" than the rest of them, and

61 Cf. Gen 41:49.

62 Cf. J. Fowler, Stufen des Glaubens: Die Psychologie der menschlichen Entwicklung und die Suche nach Sinn, Gütersloh 1991, p. 311.

63 Cf. I. M. Rupnik, „Brate iščem“, p. 77.

64 Cf. Gen 41:57.

65 Cf. Gen 42:1-4. 
does not belong to their clan. Despite Benjamin's attempts to provide equal communication, the father saw him differently than the rest of them who were Leah's and both of the maidservants' children. ${ }^{66}$ Apart from that, Benjamin, as Rachel's son, stirred their conscience, because he often reminded them of Joseph.

God knows, how the brothers felt when they headed for Egypt. They know that somewhere in that land their brother lives, if he managed to survive. The Bible does not give an account of their conversations while they travel for the first time. But from the decisions that they later make, after Joseph forces them to reflect and process their actions with his harsh treatment, we can conclude that Joseph was always present in their conversations.

\section{Joseph tests his brothers and educates them}

When his brothers arrive in Egypt, Joseph experiences the fulfilment of his adolescent dreams for the second time, especially of his first dream. His brothers arrive because of the "sheaves of grain," and just like the "sheaves in his dream," they bow to him. ${ }^{67}$ Joseph recognizes them, but they do not recognize him. ${ }^{68}$ He remembers the time that he spent with them and provokes them with interesting methods, encouraging them to remember that time and relive it. In comparison with the well, in which they had thrown him, the roles have now changed. With his harsh and relentless treatment, he forces them to think about their lives and reflect on the past, but at the same time, to speak the truth and not evade his questions. He makes it clear that evasion will not end well for them.

Joseph gets a quick glimpse of the situation back at home. He does not need thorough explanations and descriptions, and he quickly recognizes and understands what they have left out and only slightly hinted. An ambiguous

\footnotetext{
66 Cf. J. N. Cohen, Self, struggle \& change: family conflict stories in Genesis and their healing insights for our lives, Woodstock 1995, p. 175.

67 "When Joseph's brothers came, they bowed down to him with their faces to the ground" (Gen 42:6).

68 "He recognized them as soon as he saw them. But he concealed his own identity from them and spoke harshly to them. 'Where do you come from?' he asked them. They answered, "From the land of Canaan, to buy food"' (Gen 42:7).
} 
answer about the "brother, who is no more" must really speak to him. ${ }^{69}$ The brothers, when they talk about their family, feel tense and uneasy, but with his new demands, Joseph forces them to reflect further and admit their mistakes and sins. ${ }^{70} \mathrm{He}$ uses consistent and distanced communication to control his motions. ${ }^{71}$ He knows that he has to control his emotions, because they can only then express his strength, which is necessary for his brothers' to learn a deep holistic process of transformation. ${ }^{72}$

Joseph then, during their first meeting relentlessly tests his brothers and constantly demands new things from them. First he accuses them of spying, and then locks them up for three days without explanation. ${ }^{73}$ Then he keeps Simeon, one of the brothers, while he fills the bags of the others with goods, and lets them go back home. In order to force a deeper experience on them, he includes the demand to bring Benjamin, their youngest brother, who was, after Joseph, their father's second most favorite son. ${ }^{74} \mathrm{He}$ gives his brothers a taste of his own life. He accuses them of sins of which they used to accuse him; without any real argument he imprisons them, which is what happened to him; he demands that the father's favorite son be excluded from their family, which is what they demanded by excluding Joseph; he "kidnaps" Simeon, just like he was kidnapped. At the same time he almost

69 "'We your servants," they said, 'are twelve brothers, sons of a certain man in Canaan; but the youngest one is at present with our father, and the other one is no more"' (Gen 42:13).

70 "To one another, however, they said: 'Truly we are being punished because of our brother. We saw the anguish of his heart when he pleaded with us, yet we would not listen. That is why this anguish has now come upon us"' (Gen 42:21).

71 "They did not know, of course, that Joseph understood what they said, since he spoke with them through an interpreter. But turning away from them, he wept. When he was able to speak to them again..." (Gen 42:23-24).

72 Cf. D. R. Bell, Biblical models of handling conflict, Vancouver 2001, p. 48.

73 Cf. Gen 42:17.

74 "[Joseph] was reminded of the dreams he had about them. He said to them: 'You are spies. You have come to see the weak points of the land.' 'No, my lord,' they replied. 'On the contrary, your servants have come to buy food. [...] This is how you shall be tested: I swear by the life of Pharaoh that you shall not leave here unless your youngest brother comes here. So send one of your number to get your brother, while the rest of you stay here under arrest. [...] With that, he locked them up in the guardhouse for three days. On the third day Joseph said to them: 'Do this, and you shall live; for I am a God-fearing man. If you are honest men, let one of your brothers be confined in this prison, while the rest of you go and take home grain for your starving families. But you must bring me your youngest brother. Your words will thus be verified, and you will not die.' To this they agreed" (Gen 42:9-20). 
literally brings his adolescent dreams to life, in which "the sheaves and stars bow to him." Now the realization of the dream, after long and difficult trials and catharsis, is purified from narcissism and portrays a new, adult, and responsible Joseph. ${ }^{75}$

Joseph's brothers face new challenges to reflect, when they notice their money, which they used to pay for the grain, in their bags. ${ }^{76}$ On the one hand, Joseph was incredibly demanding of them, but on the other, he was unexplainably kind. In this tension, they finally connect these events to God for the first time. ${ }^{77}$

When they come home, they relay these events to their father Jacob, who also does not understand them. He is increasingly upset and worried, because the foundations upon which he had built his life are shattering. ${ }^{78}$ The brothers, headed by Reuben and Judah, plead with their father but he refuses to let Benjamin go with them to Egypt. When Jacob, after he was being convincing for a long time finally gives in, based on his positive experiences, encourages his sons to be honest. As if he was reliving his preparation for reconciliation with Esau, and intuitively foresees the possibility of reconciliation, he prepares the gifts for "the man."79

Joseph connects education with a meal. ${ }^{80}$ Here begins a holistic communication and delivering of messages, which in line with true "methodology," leads changed relationships on intrapersonal and interpersonal levels.

Understandably, the brothers fear new trials, because they face unexpected and confusing situations. ${ }^{81}$ But Joseph uses the meal as an excuse for conversation, and especially for emotional preparation for reconciliation; during the meal, he also inflicts new trials of his brothers, which are necessary

75 Cf. T. Watt, Joseph's dreams, in: Jung and the interpretation of the Bible..., p. 68.

76 Cf. Gen 42:26-27.

77 "'My money has been returned! Here it is in my bag!' At that their hearts sank. Trembling, they asked one another, 'What is this that God has done to us?"' (Gen 42:28).

78 "Must you make me childless? Joseph is no more, Simeon is no more, and now you would take Benjamin away! All these things have happened to me!" (Gen 42:36).

79 "Take your brother, too, and be off on your way back to the man. May God Almighty grant you mercy in the presence of the man, so that he may let your other brother go, as well as Benjamin. As for me, if I am to suffer bereavement, I shall suffer it.' So the men took those gifts and double the money and Benjamin" (Gen 43:13-15).

80 Cf. Gen 43:16.

81 Cf. Gen 43:18-23. 
for them to mature for reconciliation. ${ }^{82}$ When, after a pleasant meal together, they, in good mood, set on their journey home, Joseph's steward catches up with them, and demands that the brother, who is in possession of the allegedly stolen goblet, stay in Egypt. Again, all of their money was returned to them, and the goblet planted. As expected, the steward finds it with Benjamin, which saddens and scares the brothers. ${ }^{83}$

Judah takes his brothers back to mediate with Joseph, prepares a request for forgiveness, and in accordance with the promise to his father, offers his life for Benjamin. ${ }^{84}$ Joseph must be surprised to see a changed, completely different Judah, who years ago sold his brother for twenty pieces of silver, but is now willing to sacrifice anything for Benjamin. ${ }^{85} \mathrm{Judah}$ is able to learn and change through his mistakes and sins, which impresses Joseph. Judah's petition for Benjamin and his offer of sacrifice reveal that the brothers are no longer simply buyers of grain, but are sons of the same father. ${ }^{86}$ Only after Joseph had educated them and they started talking to and acting towards

82 "When Joseph came home, they presented him with the gifts they had brought inside, while they bowed down before him to the ground. After inquiring how they were, he asked them, 'And how is your aged father, of whom you spoke? Is he still alive?' 'Your servant our father is still alive and doing well', they said, as they knelt and bowed down. Then Joseph looked up and saw Benjamin, his brother, the son of his mother. He asked, 'Is this your youngest brother, of whom you told me?' Then he said to him, 'May God be gracious to you, my son!' With that, Joseph hurried out, for he was so overcome with affection for his brother that he was on the verge of tears. So he went into a private room and wept there. After washing his face, he reappeared and, now having collected himself, gave the order, 'Serve the meal.' [...] they looked at one another in amazement [...] Benjamin's portion was five times as large as anyone else's. So they drank freely and made merry with him" (Gen 43:26-34).

83 Cf. Gen 44:1-13.

84 "When Judah and his brothers entered Joseph's house, he was still there; so they flung themselves on the ground before him. [...] Judah replied: 'What can we say to my lord? How can we plead or how try to prove our innocence? God has uncovered your servants' guilt. Here we are, then, the slaves of my lord - the rest of us no less than the one in whose possession the goblet was found.' Joseph said, 'Far be it from me to act thus! Only the one in whose possession the goblet was found shall become my slave; the rest of you may go back unharmed to your father.' Judah then stepped up to him and said: [...] 'So now let me, your servant, remain in place of the boy as the slave of my lord, and let the boy go back with his brothers. How could I go back to my father if the boy were not with me? I could not bear to see the anguish that would overcome my father"' (Gen 44:13-34).

85 Judah's plea for Benjamin is the longest talk in Genesis (Cf. E. J. Hartley, New international biblical commentary..., p. 339).

86 Cf. I. M. Rupnik, "Brate iščem", pp. 100-101. 
each other as brothers, can he accept them as such and become their brother again too. ${ }^{87}$

\subsection{Joseph reconciles with his brothers for the first time}

Joseph was able to control his emotions many times before, but this time he could not. ${ }^{88}$

With all of his trials, Joseph prepared his brothers for reconciliation. If he revealed who he was at their first meeting, his brothers probably never would have grasped the depth of the reunion, which could have led to them trying to take advantage of him again. Perhaps the brothers, without deeper contemplation, would have taken the meeting as an opportunity for privileges. This would have prevented genuine communication, because they would not recognize Joseph as a brother, but as someone, who "has to" do them a favor because of his position. Because Joseph was able to control himself and not reveal himself immediately, he forced them to reflect and wrestle with the "god of the past" with his always-increasing challenges; in other words, to recognize their sin and accept their sinful acts. All this tension softens the past for the brothers and sensitizes them for relationships. Joseph, therefore, with a persisting distanced communication - which is emotionally extremely challenging - prepares himself and his brothers for a reconciliatory meeting. This meeting of the brothers does not only entail admission of sin and Joseph's forgiveness, but for Joseph in particular, recognizing the "purpose" of sin, as a sort of "happy fault," which gives new purpose to sinful actions. The brothers'

87 Cf. B. Roebben, Living and learning..., p. 28.

88 "Joseph could no longer restrain himself in the presence of all his attendants, so he cried out, 'Have everyone withdraw from me!' So no one attended him when he made himself known to his brothers. But his sobs were so loud that the Egyptians heard him, and so the news reached Pharaoh's house. 'I am Joseph,' he said to his brothers. 'Is my father still alive?' But his brothers could give him no answer, so dumbfounded were they at him. 'Come closer to me', Joseph told his brothers. When they had done so, he said: 'I am your brother Joseph, whom you sold into Egypt. But now do not be distressed, and do not be angry with yourselves for having sold me here. It was really for the sake of saving lives that God sent me here ahead of you. [...] Hurry back, then, to my father and tell him: «Thus says your son Joseph: God has made me lord of all Egypt; come down to me without delay. [...] Tell my father all about my high position in Egypt and all that you have seen. But hurry and bring my father down here.»' Then he threw his arms around his brother Benjamin and wept on his shoulder. Joseph then kissed all his brothers and wept over them; and only then were his brothers able to talk with him" (Gen 45:1-15). 
sin has become a means for salvation, which is why, in Christology, Joseph takes on a role of a character, who announces Christ.

The biblical drama is too experientially challenging and unpredictable to evade it by "acting." Joseph had to endure through different trials and through them educate himself and his brothers. None of his steps were free, revealed to him ahead of time, or spared for him. With him, things were always very serious. Only serious self-education brought true reconciliation, on generational and cross-generational levels, because he meets his brothers and his father.

\subsection{Jacob and Israel in Egypt; Joseph's reconciliation with his father}

Alone and lonely, while his children were in Egypt, Jacob had plenty of time to relive and process his own life. God gives him an opportunity in this desert pain, to think about his failures and success, his shadowy and sunny sides of life, the sin and grace, Jacob and Israel in him. He has discovered the intertwining Jacob's and Israel's dimensions in him, and has learned to accept himself completely, both as Jacob and Israel at the same time. In his longings, he loved Jacob, and in his feelings, he longed for Israel. As Jacob-Israel, he is filled with pain, but also with integrated past and future, which is why he awaits the return of his sons from Egypt with a deeply-rooted longing. But his mood keeps changing: sometimes pessimism and pain of Jacob are at the surface, and other times the longing and hope of Israel come out. ${ }^{89}$ The tension between the past, marked with Jacob, and with the future, filled with Israel, is active his whole life and he never truly conquers it..$^{90}$ This is true for the Old Testament Jacob, as well as for modern man, who strives to grow in faith.

His sons bring a message of salvation that his beloved son Joseph is alive. This news surpasses Jacob's "minimalistic" expectation that Benjamin would

\footnotetext{
89 "So they went up from Egypt and came to the land of Canaan, to their father Jacob. When they told him, 'Joseph is still alive - in fact, it is he who is governing all the land of Egypt,' he was unmoved, for he did not believe them. But when they recounted to him all that Joseph had told them, and when he saw the wagons that Joseph had sent to transport him, the spirit of their father Jacob came to life. 'Enough,' said Israel. 'My son Joseph is still alive! I must go and see him before I die"' (Gen 45:25-28).

90 Cf. J. N. Cohen, Voices from Genesis..., pp. 130-131.
} 
return alive, which is why he is more joyful than he had recently dared to hope. As the lost son, or brother, Joseph invites his father Jacob, as well as his brothers and their families to Egypt, and thus becomes their "savior." Jacob finally feels that he has actually become an integrated, and a truly educated person who comparatively recognizes and accepts Jacob and Israel as complements.

The Bible is seemingly toying with the usage of names Jacob and Israel, but in reality this reveals the hidden dynamics of Jacob's, or Israel's, inner world. When Jacob is thinking about the future, he sees himself as Israel, but when he faces the past, he reacts as Jacob. When he sub-consciously identifies himself (to God and to himself) as Jacob, he is able to accept God's promises, which allows him to actually become "Israel." From Beer-Sheba he arises as "Jacob" and his children accept him as such. ${ }^{91}$ But in the context of the whole Bible, the children are at this point no longer "Jacob's, but "Israel's." However, the moment that the Bible shifts to chronology, "Israel's" children become "Jacob's" again, because they were born as such. ${ }^{92}$

Names have an important role in Semitic literature, because they usually portray "essential content." In this sense, the above-mentioned interpretation probably fleetingly, and from the biblical exegesis' point of view, nonscientifically, touches upon of a very interesting phenomenon. Even though these parts of the interpretation are merely hypothetical, and therefore do not demand a thorough biblical research methodology, such examples speak loudly in the context of a deep intuition and a holistic insight into the challenges of upbringing. They motivate us, as biblical non-scholars, to see the Bible as a source of inexhaustible wisdom, which always, in every circumstance, speaks to us in different ways, and on different levels.

So Joseph invites Jacob, his children, and their families to Egypt. This time, he also sends a spokesperson ahead, his son Judah, who thought of himself as a lead negotiator from the beginning. ${ }^{93}$

91 Cf. Gen 46:5.

92 "So Jacob and all his descendants came to Egypt. His sons and his grandsons, his daughters and his granddaughters - all his descendants - he took with him to Egypt. These are the names of the Israelites, Jacob and his children, who came to Egypt. Reuben, Jacob's firstborn..." (Gen 46:6-8).

93 "Israel had sent Judah ahead to Joseph, so that he might meet him in Goshen. On his arrival in the region of Goshen, Joseph prepared his chariot and went up to meet his father Israel in Goshen. As soon as Israel made his appearance, Joseph threw his arms around him 
Joseph thus sets out to meet Jacob. Jacob and Joseph never had an open disagreement or argument, but we can still assume that at the moment of the unforeseen separation, they left some open questions and tension in their relationship. Joseph's dreams hurt Jacob also, and Joseph might have had a difficult time accepting that his father sent him to his brothers unprotected. They must have both had bitter memories of the separation, and felt like their relationship needed healing. As a matter of fact, this long and uncertain separation is a consequence of their relationship. When they cry and hug they share a lot of non-verbal communication, filled with admission of sin, asking for forgiveness, and also forgiving each other.

Jacob finds so much peace in this reconciliatory embrace, that - understanding the communal dimension of the meeting - speaks to Joseph as "Israel." After reconciliation with his brothers and father, Joseph provided the best living conditions for the whole family. ${ }^{94}$

\subsection{Jacob blesses and heads "home"}

After his reconciliation with Joseph, Jacob keeps communicating with his son as Israel. At first he asks him to be buried with his fathers, in his home town. ${ }^{95}$ Thus his dynamic journey through life will end at home, with his "fathers." His longing for the "fatherland" spans from his birth to his death, and fundamentally influences his decisions and actions.

When he grew old, Jacob emotionally returned to his childhood years and events. We could say that as an "old man" he set in his childhood ways. According to his childhood habits, before he says goodbye, he wants to ask not his brother this time, but his son - to swear to him that he will do as he promised. ${ }^{96}$

and wept a long time on his shoulder. And Israel said to Joseph, 'At last I can die, now that I have seen for myself that you are still alive"' (Gen 46:28-30).

94 "Pharaoh said to Joseph, 'Now that your father and your brothers have come to you, the land of Egypt is at your disposal; settle your father and brothers in the pick of the land. Let them settle in the region of Goshen. And if you know of capable men among them, put them in charge of my livestock"' (Gen 47:5-6).

95 Cf. Gen 47:30.

96 "But his father demanded, 'Swear it to me!' So Joseph swore to him. Then Israel bowed at the head of the bed" (Gen 47:31). 
Before his death, Jacob, that is Israel, wishes to bless Joseph and his sons. Like his father Isaac before him, Israel grew old and almost tuned blind by the time this moment arrived. ${ }^{97}$

Jacob, as a father, is aware of his mistakes, and now, as a grandfather, wants to at least partially fix some of them. In accordance with these and other fatherly longings for fertility and a blessed future, he asks his son Joseph if his grandsons could "belong" to him a little - not as much as Joseph does, but more like Reuben and Simeon do. ${ }^{98}$ Even though he knows that Joseph's sons are fruits of Rachel's love, who is now deceased but particularly comes to life in Jacob during the time of blessing, Jacob justifies his request by referring to the names of Leah's sons Reuben and Simeon. Therefore, along with some obvious signs of old age - in fundamental moments - and dimensions that are vitally important for the future, Jacob's wisdom shines too. By blessing Joseph's sons as Reuben and Simeon, he recognizes and blesses Rachel the same way as Leah, and vice versa. In Jacob's blessing of his descendants, his wives Leah and Rachel become existentially connected again.

After many painful experiences and discoveries, Jacob is aware of complications and pain, which are caused by privileges and unfair upbringing. He remembers his childhood and youth mostly as being "disadvantaged" by his father. As a father, he also bestowed privileges, especially to Joseph, and therefore knows what unjust communication feels like. This is why now, as a grandfather, he wants his blessing to be fairer, and he tries to provide a good starting point for both of his grandchildren's future. ${ }^{99}$

Unlike his father, Jacob blesses both of Joseph's sons, but not both in the same way. In spite of Joseph's protest, he gives the younger one an advantage,

97 Cf. Gen 48:10.

98 "So now your two sons who were born to you in the land of Egypt before I joined you here, shall be mine; Ephraim and Manasseh shall be mine as much as Reuben and Simeon are mine. Progeny born to you after them shall remain yours; but their heritage shall be recorded in the names of their brothers" (Gen 48:5-6).

99 "Then Joseph took the two, Ephraim with his right hand, to Israel's left, and Manasseh with his left hand, to Israel's right, and brought them up to him. But Israel, crossing his hands, put out his right hand and laid it on the head of Ephraim, although he was the younger, and his left hand on the head of Manasseh, although he was the firstborn. [...] When Joseph saw that his father had laid his right hand on Ephraim's head, this seemed wrong to him; so he took hold of his father's hand, to remove it from Ephraim's head to Manasseh's, saying, 'That is not right, father; the other one is the firstborn; lay your right hand on his head!' But his 
as if he recognized the psychological tendencies of family systems, which in one way predicts better results for the younger son, usually the second-born, not the firstborn. He does not need to psychologically analyze them to make his decision, because his experience has taught him that, and it leads him to the same conclusion.

Before he dies, Jacob blesses his other sons too. ${ }^{100}$ The longest, actually the firstborn blessing goes to Joseph. ${ }^{101}$

\subsection{Joseph's second, and final reconciliation}

After Jacob's death, Joseph's brothers live in fear again, when they face new circumstances. Perhaps they still do not know Joseph enough and think that he is incapable of real and complete forgiveness, which is why they again ask him for forgiveness in the name of their father. ${ }^{102}$

Thus, Joseph and his brothers, after their father's death, thoroughly clean their wounds form the past and form genuine relationships, which continue even after Joseph's death. They find this new catharsis necessary, probably because of Joseph's initial harsh treatment, which kept them on the "defensive" long enough that they looked inside and relived their past in a purifying

father refused. 'I know it, son', he said, 'I know. That one too shall become a people, and he too shall be great. Nevertheless, his younger brother shall surpass him, and his descendants shall become a multitude of nations.'

So he blessed them that day and said, 'By you shall the people of Israel pronounce blessings, saying, "God make you like Ephraim and Manasseh.»' Thus he placed Ephraim before Manasseh" (Gen 48:13-20).

100 Cf. Gen 49:1-28.

101 Cf. E. J. Hartley, New international biblical commentary..., p. 359.

102 "Now that their father was dead, Joseph's brothers became fearful and thought, 'Suppose Joseph has been nursing a grudge against us and now most certainly will pay us back in full for all the wrong we did him!' So they sent to Joseph and said: 'Before your father died, he gave us these instructions: «Thus you shall say to Joseph: Please forgive the criminal wrongdoing of your brothers, who treated you harmfully.» So now please forgive the crime that we, the servants of the God of your father, committed.' When they said this to him, Joseph broke into tears.

Then his brothers also proceeded to fling themselves down before him and said, 'We are your slaves!' But Joseph replied to them: 'Do not fear. Can I take the place of God? Even though you meant harm to me, God meant it for good, to achieve this present end, the survival of many people. So now, do not fear. I will provide for you and for your children.' By thus speaking kindly to them, he reassured them" (Gen 50:15-21). 
way. ${ }^{103}$ But Joseph again proves to be a deeply faithful and religious person, who sees past the natural signs, and recognizes a deeper meaning, God's intimacy, and goodness even in painful experiences. After the brothers' have been purified, they do not need to be "tortured" anymore. Along with his generous and permanent forgiveness, Joseph indirectly explains to them that his harsh treatment was intended purely for their own benefit and education, and was, in fact, necessary for them. After reconciliation there is not more tension, which also shows that the long process of reconciliation is finalized.

\section{Conclusion}

Joseph was creating conflicts, because he was privileged by his father. At the same time, it is good to be aware that Joseph's father Jacob was also the brother of privileged Esau, with whom he was also in conflict for a big part of his life. The reason for conflicts between the brothers, Jacob and Esau, can probably be found in the tensions between their parents, Isaac and Rebekah. ${ }^{104}$ These two more or less repeated the pattern of conflicting communication committed by their parents, Abraham and Sarah. It is known that in times of famine, which can be understood as the plight in the marital relationship, they proposed to their wives not to disclose themselves as wives, but as sisters of their husbands.

Interestingly, in the first Abraham's generation this happened precisely in Egypt; so there, where the conflicts started in the first place. Joseph thus in four generations represents the first man who changed in his life so much that was able to turn from the culprit of conflicts into the resolver of conflicts. It is true, however, that his changes also led to changes in his brothers. This means that we are able to resolve conflicts within a family only if we all change. If we take into account the dynamics of relationships in all four generations, it also means that conflicts are finally resolved there where they arose. In Egypt, namely, first discrepancies between Abraham and Sarah took place, and in Egypt, final reconciliation occurred.

103 Cf. E. J. Hartley, New international biblical commentary..., pp. 331-332.

104 Cf. M. K. Adams, Po tihem zapeljani: Ko si starši otroke naredijo za partnerje, Ljubljana 2013, p. 24-25. 


\section{Bibliography}

Adams M. K., Po tihem zapeljani: Ko si starši otroke naredijo za partnerje, Ljubljana 2013.

Bell D. R., Biblical models of handling conflict, Vancouver 2001.

Bogzaran F., Deslauriers D., Intergal deraming: a holistic approach to dreams, New York 2013.

Cavalletti S., The religious potential of the child 6 to 12 years old, Chicago 2002.

Cloud H., Townsend J., How people grow: what the Bible reveals about personal growth, Grand Rapids 2001.

Cohen J. N., Self, struggle \& change: family conflict stories in Genesis and their healing insights for our lives, Woodstock 1995.

Cohen J. N., Voices from Genesis: guiding us through the stages of life, Woodstock 1998.

Fincham D. F., I say a little prayer for you, in: Contemporary issues in family studies, eds. A. Abela, J. Walker, Oxford 2014, pp. 341-354.

Fowler J., Stufen des Glaubens: Die Psychologie der menschlichen Entwicklung und die Suche nach Sinn, Gütersloh 1991.

Hartley E. J., New international biblical commentary: Genesis, Peabody 2000.

Janzen J. G., Exodus, Louisville 1997.

Roebben B., Living and learning in the presence of other defining religious education inclusively, in: Inclusive religious education: international perspectives, eds. B. Roebben, K. Kammeyer, Berlin-Zürich 2014, pp. 13-32.

Rupnik I. M., "Brate iščem”, Koper 2000.

Sveto pismo Stare in Nove zaveze: Slovenski standardni prevod iz izvirnih jezikov, Ljubljana 1997.

Walton H. J., The NIV application commentary: from biblical text... to contemporary life, Grand Rapids 2001.

Watt T., Joseph's dreams, in: Jung and the interpretation of the Bible, ed. L. D. Miller, New York 1995, pp. 55-70. 